\title{
Ergonomic intervention methods for inclusion of people with disabilities at work: Brazilian scene
}

\author{
Cabral, A. K. P. S. ${ }^{\mathrm{a}^{*}}$, Martins, L. B. ${ }^{\mathrm{b}}$, \\ a Senior Lecturer, Department of Occupational Therapy, Federal University of Pernambuco, Av. Professor \\ Moraes Rego, 1235, CEP 50670-901, Cidade Universitária, Recife, PE, Brazil. E-mail: \\ anakarinapessoa@yahoo.com.br \\ b Senior Lecturer, Department of Design, Federal University of Pernambuco, Av. Professor Moraes Rego, 1235, \\ CEP 50670-901, Cidade Universitária, Recife, PE, Brazil.
}

\begin{abstract}
The aim is to identify ergonomic intervention methods used for including people with disabilities (PD) in the Brazilian labor market, with emphasis on discussion of methods to analyze the fit between the worker and the workplace. Methods to evaluate the fit of the worker to the workplace identify the capabilities and limitations of PDs and the demands of work, combining these data, and comparing them, in order to obtain a detailed analysis of the fit were drawn from national and international publications. These show that the use of specific methods for PDs and others focused on the general population. Mutatis mutandis, there is a need for complementary tools to address this segment. Thus, for the Brazilian scenario, it is essential to develop specific methodological tools to assess the capabilities of a PD so that they may better interact with their job.
\end{abstract}

Keywords : Ergonomics, Work, Disabilities, Inclusion

\section{Introduction}

It is unique to the essence of humanity to have the capacity to create and recreate nature and the world around them through their own work and production. Therefore, this paper represents an instrument of mediation between people and the world around them, from which they transform things, relationships and themselves. This process helps to affirm humanity's existence and to provide dignity and citizenship.

In this context, the opportunity to engage in professional activities constitutes a social right for all citizens, guaranteed by governments, in Brazil and worldwide. However, it is well known that episodes of discrimination often occur and there is a lack of preparing people on how to respond to people with a disability (PD) and to provide access to many everyday activities, such as work, which has left PDs on the fringes of the possibilities of personal/ professional ascent and of contributing the development of society.

According to WHO (2003), PDs represent $10 \%$ of the world population, namely, 610 million people, among whom $80 \%$ live in developing countries such as Brazil [17].

In Brazil, according to data from the 2010 Census of the Brazilian Institute of Geography and Statistics [11], approximately $23.91 \%$ of the population, i.e. 45.6 million people have some kind of disability, which is higher than the world percentage. This difference is even more evident in the Northeast of Brazil, where the rate reaches $30.97 \%$, probably due to

" Corresponding author: Department of Occupational Therapy, Federal University of Pernambuco, Av. Professor Moraes Rego, 1235, CEP 50670-901, Cidade Universitária, Recife, PE, Brazil. Tel: (55 81)2126 8931/2126 8495. E-mail: anakarinapessoa@yahoo.com.br. $1051-9815 / 12 / \$ 27.50 @ 2012$ - IOS Press and the authors. All rights reserved 
poor socio-economic, sanitary and educational conditions.

In an attempt to ensure the inclusion of this population in the labor market, Brazilian law has a number of legal instruments, such as Decree No 3.298/1999 which sets out the National Policy for the Integration of Persons with Disabilities [5], and Laws No 8.112/1990 (Quota Law) and No 10.098/2000 that determine, respectively, the obligation of (public or private) companies to hire people with disabilities onto their staff and by setting standards for fostering accessibility to them $[6,7]$.

At the national level, there has also been the creation of the National Coordination Unit for the Integration of People with Disabilities (CORDE in Portuguese), an advisory body of the Secretary of State for Human Rights, Ministry of Justice, the function of which is to implement policies aimed at integrating PDs, in a multidisciplinary way, the focal axis being the advocacy and promotion of citizenship.

However it is found that, despite the broad legal framework in favor of the issue, only about $4 \%$ of PDs in Brazil are included in professional activities. According to IERS - the Ethos Institute for Social Responsibility (2006), in Brazil, professional activities are performed on a remunerative basis by $1,000,000$ PDs, amongst whom only 200,000 are formally employed with Labor Law rights [12].

Frequently, in businesses, the number of employees with disabilities is limited to the legal requirement and they are usually placed in functions that are not valued and have only marginal possibilities of advancing their career [3].

For Barbosa Filho (2004), legal requirements, such as the Law on Quotas, appear as if they were an imposition for which Brazilian society is not ready [2]. As an example, it is noted that companies also have doubts as to selecting and training PDs regarding their productive capacity, accessibility and appropriateness of the jobs, safety procedures; in sum, about a number of issues.

In this context, Ergonomics is an important tool within organizations because it makes it possible to match up spaces, jobs and work tools to all workers, including those with a disability. In the latter case, it has become indispensable because it adjusts the demands of work to the specific needs of this population.

As per IIDA (2005), there are various fields of work yet barely explored by ergonomics, such as the situation which involves PDs in the Brazilian labor market [13]. Moraes (2001), corroborating this state- ment, points out that in Brazil there is a great need for the production of ergonomic research studies in this area, especially with regard to ergonomic methodologies that target analysing and adapting jobs for PDs [15].

Some studies found in the Brazilian literature, on this issue, such as those of Bissig (2004), Normann (2004), Ribeiro Vieira and Másculo (2005) and Rosa (2003) suggest several methods and techniques for the inclusion of PDs in various fields of work, from the perspective of Ergonomics, which, according to these authors, have presented significant results.

When the experiences of other countries are analysed, there are several methods and techniques used selecting and placing PDs in professional activities. It has become important to learn about them and their contributions in order to create parameters for using methods and techniques in Brazil, by adapting them to this reality.

Thus, this paper sets out to identify ergonomic intervention methods used for including PDs in jobs, with an emphasis on discussing methods of analysing how to match the worker and the job, which will be used by researchers in Brazil.

\section{Materials and Method}

This research is classified as exploratory, with a view to enhancing ideas and obtaining greater familiarity with the problem [8]. As to defining it, a review of the literature was conducted based on material already prepared, consisting mainly of books and scientific articles [14].

The review of the literature review was performed, with data collected over the past 15 years, in English, Portuguese and Spanish. We analysed 51 publications, $67 \%$ in Brazil and 33\% in other countries, which provided evidence of the use of some methods of ergonomic intervention for PDs, such as: the Method of the Ergonomic Analysis of Work AET; the Method of the Macro-ergonomic Analysis of Work - AMT; the ErgoDis Method/ IBV; the Ertomis Assessment Method - EAM; the Activity Matching Ability System - AMAS; and the Method of Ergonomic Analysis of the Capabilities of a Worker and of the Requirements of a Work Situation MAECES; the ESAP Method - Evaluation Systémique Professionnelle des Aptitudes; and the ANACT Method - Agence Nationale Pour L'amelioration des conditions de Travail.

Data collection occurred through reference books, publications in journals and conference proceedings, master's dissertations and doctoral theses, available 
in collections of the libraries of the Federal University of Pernambuco and Catholic University of Pernambuco; the proceedings of national and international scientific congresses and databases (COMPENDEX, LILACS, WEB OF SCIENCE, SCIELO, APPLIED ERGONOMICS, INTERNATIONAL JOURNAL OF INDUSTRIAL ERGONOMICS).

\section{Methods of ergonomic intervention for the inclusion of people in workplaces: emphasis on the Brazilian scenario}

Several methods and techniques are used by ergonomists for the professional (re-)integration of PDs, each with its own specific applications and characteristics that are able to promote an appropriate placement of these people into jobs, by matching the task to the specificities of the subject, taking his/her abilities and limitations into account.

Bloswick and Hinckley (2004) and Tortosa et al. (1997) argue that when evaluating and adapting a job for a PD, information must be obtained on the functional capacity of the subject and the demands of the task determined [4, 24]. The comparison of these two topics is needed so as to propose necessary intervention measures. Tortosa et al. (1997) add that the simultaneous analysis of the demands of work and the capabilities of the subject allows possible adjustments or maladjustments to be detected [24].

In summary, studies were identified on methods and techniques used in work situations of the population at large, along with some applications for PDs, such as the Ergonomic Analysis of Work (EWA) and the Macro-ergonomics Analysis of Work (AMT), as well as the use of specific methodologies, such as the ErgoDis Methods, EAM, AMAS, MAECES, ESAP and ANACT, which were created to facilitate the inclusion of PDs in the labor market, as per Table 1.

Table 1

Methods of Ergonomic Intervention

\begin{tabular}{|c|l|}
\hline \multicolumn{1}{|c|}{ Methods } & \multicolumn{2}{|c|}{ Authors } \\
\hline $\begin{array}{c}\text { Ergonomic Analysis of } \\
\text { Work (AET) }\end{array}$ & \multicolumn{1}{|c|}{ Guimarães (2003); } \\
& Hoffman (2002); Medeiros \\
& Neto (2004); Nakamura \\
& $(2003) ;$ Oliveira (2002); \\
& Ribeiro (2005); Ribeiro, \\
& Vieira e Másculo (2005); \\
& Tomaz et al. (2002) \\
\hline Macro-ergonomic Analysis & Bitencourt, Guimarães e \\
of Work (AMT) & Saurin (2004); Bitencourt et \\
& al. (2006; 2005); Harris \\
& Ferreras et al. (2006); \\
\hline ErgoDis/IBV Method & \multicolumn{2}{|c|}{} \\
\hline
\end{tabular}

\begin{tabular}{|c|c|}
\hline & $\begin{array}{l}\text { Latonda e Molina (2002); } \\
\text { Remesal (2001); Remesal e } \\
\text { Latonda (2003); Tortosa et } \\
\text { al. (1997) }\end{array}$ \\
\hline $\begin{array}{c}\text { EAM Method - Ertomis } \\
\text { Assessment Method }\end{array}$ & $\begin{array}{l}\text { Jochheim et al. (1993); } \\
\text { Tortosa et al. (1997) }\end{array}$ \\
\hline $\begin{array}{l}\text { AMAS System - Activity } \\
\text { Matching Ability System) }\end{array}$ & $\begin{array}{c}\text { Tortosa et al. (1997); } \\
\text { Watson et al. (1990) }\end{array}$ \\
\hline MAECES Method & $\begin{array}{l}\text { Barbosa (2007); Therri- } \\
\text { ault (1998); Therriault e } \\
\text { Lavoie (2004); Therriault; } \\
\text { Lavoie; Lavoie (2006) }\end{array}$ \\
\hline $\begin{array}{l}\text { ESAP Method - Evaluation } \\
\text { Systémique dês Aptitudes } \\
\text { Professionnelles }\end{array}$ & $\begin{array}{l}\text { Villers et al. (2002) apud } \\
\text { Barbosa (2007) }\end{array}$ \\
\hline $\begin{array}{l}\text { ANACT Method - Agence } \\
\text { Nationale Pour L`Amelioration } \\
\text { Des Conditions De Travail }\end{array}$ & $\begin{array}{l}\text { Tomaz (2002); Tomaz et } \\
\text { al. (2004); Velázquez et al. } \\
\text { (1995) }\end{array}$ \\
\hline
\end{tabular}

What was found to predominate in Brazil was the AET method, followed by the AMT method, which, because they are not specifically for analyzing PDs' work, were used along with other evaluation tools such as interviews, systematic observations and questionnaires. On the other hand, the ErGodis/IBV Method was the most cited in the international literature. It is by the Institute of Biomechanics of Valencia/Polytechnic University of Valencia/Spain, and was created exclusively for (re-)integrating PDs into the labor market.

The Ergonomic Analysis of Work (EWA in Portuguese), by Santos and Fialho (1997), claims to understand demand, the prescribed and real work, its problems and possible solutions [20]. For this approach, of the real context of work, qualitative methods are generally used [20]. The example can be cited of the moment of confrontation between 'prescribed and real' work, in which prescriptive documents of the company are counterpointed with what is observed in the reality of work and described by the workers who perform these activities. It is only at this stage that three tools of the qualitative approach are used: document analysis, direct observation (whether or not as a participant) and the interview or focus group.

The Macro-ergonomic Analysis of Work (AMT in Portuguese) proposed by Guimarães (1999) is a method of ergonomic action that takes a participatory approach and which, when applied to companies, has the methodological orientation of action research [9]. A type of empirical social research which is designed and carried out in close association with an action or to solve a collective problem and in which the researchers and participants representative of the situation or problem are involved in a co-operative or participatory way, as proposed by Thiollent (1994) [10]. 
AMT intends, above all, to contribute to improving the quality of life and work and thus, comes from the organization, undergoes the process until one reaches the job.

It was found that both the AET and AMT were not created specifically for PDs in work situations, thus making it necessary to take a closer look and use complementary techniques for data collection. Therefore, these authors used techniques such as questionnaires, interviews, systematic observations and checklists to complement data collection about PDs and their jobs.

Tortosa et al. (1997) highlight the main methods developed to adapt jobs specifically to PDs [24]. EAM and AMAS methods compare the profile of the capacity of the subject and the profile of the job requirements, thus seeking to adjust work to the subject (Jochheim et al., 1993), while ErGodis/IBV combines this procedure with an analysis of ergonomic risks [24].

In Brazil, some studies have pointed out the advantages in the use of methods of analysing PDs and their jobs, such as ErGodis/IBV and MAECES, which assess not only the worker's capabilities and limitations or the demands of work, in isolation, but associate these data, and comparing them in such a way as to obtain a detailed analysis of the match of subject-work.

MAECES allows a simultaneous analysis of a worker's physical and mental abilities and the physical and mental demands of a job, demonstrating precisely, the capabilities and differences between the capabilities of the worker and the demands of the job $[1,21]$.

These methods deserve special attention in view of the relevance of using them in ergonomic interventions, which makes data collection more secure, complete and systematised, mainly because they bear a similarity to and have the ability to adjust to Brazilian demands.

Other methods were also identified. The ESAP method, mentioned by Villers et al. (2002), proposes the analysis of the worker's profile, of employment or the job, and the profile of the physical environment in question, its obstacles and/or facilitators [1]. In addition, there is ANACT, cited in the research studies of Tomaz (2002), Tomaz et al. (2004) and Velazquez et al. (1995). This allows the characterization of the company and organization of work, the profile and function of the workers, the description of the task, workplace and its surroundings, postures adopted, grumbles referred to, security and comfort, and taking into account the opinions of the workers themselves and their direct line managers [22, 23, 25].

By means of the above, it was found that methods and techniques are essential to ensure the proper collection and analysis of data as well as precise intervention and the adaptation of jobs. However, none of the methods has in itself a solution for the problems detected in a given situation. In fact, they comprise only tools that are able to identify possible conflicting aspects. It is ergonomists, along with other professionals and the workers themselves, who will find and implement the ideal solution for each particular case.

\section{Conclusion}

Within the ergonomising intervention, this study focused on the analysis of using methods and techniques to collect and analyse data and thus to contribute to adjusting jobs to DPs. The method most cited in Brazilian publications was the Method of the Ergonomic Analysis of Work (EWA), followed by the Method of the Macro-ergonomic Analysis of Work (AMT), while overseas, the one in predominant use is the ErgoDis/IBV Method.

It might be found that what prevails in Brazil is the use of ergonomic intervention methods not specific to PDs. This result deserves special attention in view of the importance of using methods and techniques in ergonomic interventions, which would make data collection more secure, complete and systematic.

The present scenario in Brazil explains the early stage at which scientific research is to be found in this field (Ergonomics and Inclusion of PDs), since these methods were not drawn up for this population, namely, the techniques normally used do not address all the specificities of these individuals, thus making it necessary to support them with complementary instruments, such as scripts of interviews, questionnaires and checklists, created based on specific methods for PDs, and covering cultural issues.

It is believed that this reality is a reflection of the tradition of some researchers in the methodologies referred to (AET and AMT), apart from the insufficiency of financial incentives for the purchase of software and hence because there are few studies on methods of analysis for matching the worker with a disability to the workplace, such as ErgoDis, EAM, AMAS and MAECES.

Given the above, it is noted that there is a need to develop specific methodological instruments to assess the real capabilities and limitations of DPs vis-à- 
vis the interaction with their job, bearing in mind the scarcity of these instruments in Brazil and evidence that proves the efficiency of these methods. Is therefore recommended to invest in research that use these methods so as to validate them, considering the socio-cultural reality of Brazil, or also conducting comparative analysis of them so as to develop hybrid methods.

\section{References}

[1] Barbosa, C.S. Habilidades Escepcionais: uma avaliação das capacidades produtivas de pessoas portadoras de deficiência mental. Dissertação de mestrado profissionalizante - Escola de Engenharia. Porto Alegre: UFRGS, 2007.

[2] Barbosa Filho, A. N. Um Modelo de Avaliação da Qualidade de Vida no Trabalho par a Pessoa com Deficiência. Tese de doutorado. CTG-Engenharia de Produção. Recife: UFPE, 2004

[3] Bíssigo, M. C. K. Nível de Satisfação de Pessoas Portadoras de Deficiência Ambulatória com o trabalho e com as condições de acesso a empresas de Caxias do Sul. Dissertação de mestrado profissionalizante - Escola de Engenharia. Porto Alegre: Universidade Federal do Rio Grande do Sul, 2004.

[4] Bloswick, D. S.; Hinckley, D. Job Accommodation. In: Kumar, S. Muscle Strength. London: CRC Press, 2004.

[5] Brasil. DECRETO N ${ }^{\circ} 3.298$, DE 20 DE DEZEMBRO DE 1999. Disponível em http://www.planalto.gov.br/

[6] Brasil. LEI No. 8.112, DE 11 DE DEZEMBRO DE 1990 Disponível em http://www.planalto.gov.br/

[7] Brasil. LEI No. 10.098, DE 19 DE DEZEMBRO DE 2000. Disponível em http://www.planalto.gov.br/

[8] Gil, A. C. Como elaborar projetos de pesquisa. 4. ed. São Paulo: Atlas, 2002.

[9] Guimarães, L. B. de M. Ergonomia de Produto. 5 ed. Vol. 1. Série monográfica Ergonomia. Porto Alegre: FEENG, 2004.

[10] . Intervenção Macroergonômica em empresa do setor eletromecânico: um estudo de produtividade. In: I Encontro África-Brasil de Ergonomia, V Congresso LatinoAmericano de Ergonomia, IX Congresso Brasileiro de Ergonomia, III Seminário de Ergonomia da Bahia. Anais do ABERGO 1999. Salvador, 1999.

[11] IBGE - Instituto Brasileiro de Geografia e Estatística, 2011.

[12] IERS - Instituto Ethos de Responsabilidade Social. Disponível em: $<$ www.ethos.org.br $>$

[13] Iida. Ergonomia: projeto e produção. $2^{\mathrm{a}}$ ed. São Paulo: Edgard Blücher, 2005.

[14] Marconi, M. A.; Lakatos, E. M. Metodologia do Trabalho Científico: procedimentos básicos. Pesquisa bibliográfica Projeto e relatório. Publicações e trabalhos científicos. 6. Ed. São Paulo: Atlas, 2001.

[15] Moraes, A. Ergonomia nas Américas. Gramado: XI Congresso Brasileiro de Ergonomia. Súmula de Mesa Redonda, 2001

[16] Normann, A. F. M. Acessibilidade: os desafios ergonômicos à aplicação das normas de proteção do trabalho de pessoas portadoras de deficiência. Dissertação de mestrado apresentado no Mestrado Profissionalizante da Escola de Engenharia. Universidade Federal do rio Grande do Sul. Porto Alegre, 2004. 161 p.
[17] OMS - Organização Mundial de Saúde. Classificação Internacional de Funcionalidade, Incapacidade e Saúde CIF. São Paulo: USP, 2003.

[18] Ribeiro; J. N.; Vieira, S. B.; Másculo, F. S. O Portador de Deficiência entre a Conquista do Trabalho e o Desafio pela Inclusão em Postos Ergonomicamente Adaptados. In: II ENEDS, 2005, Rio de Janeiro/RJ, Anais...Rio de Janeiro/RJ, 2005.

[19] Rosa, N. M. F. de. As relações de trabalho da PPD: um estudo inclusivo. Dissertação de mestrado apresentado no Mestrado Profissionalizante da Escola de Engenharia. Universidade Federal do Rio Grande do Sul. Porto Alegre, 2003.

[20] Santos, N. dos; Fialho, F. A. P. Manual de analise ergonômica no trabalho. 2. ed. Curitiba: Gênesis, 1997.

[21] Therriault, P. Y.; Lavoie, M.; Lavoie, É. Maeces: a Rehabilitation ergonomics tool. In: Proceedings IEA Congress Meeting Diversity in Ergonomics, 2006, Anais...Eur. Erg. Elsevier Ltd, 2006.

[22] Tomaz, A. F. A Concepção Ergonômica da Organização do Trabalho e sua Relação com a Integração Laboral: estudo de caso com operadores de caixa portadores de deficiência física. Dissertação de Mestrado. João Pessoa: UFPB, 2002. $168 \mathrm{p}$.

[23] Tomaz, A. F. et al. Aspectos da Organização do Trabalho e Integração Laboral de Operadores de Caixa Portadores de Deficiência Física. In: VII Congresso Latino-Americano de Ergonomia. I Seminário Brasileiro de Acessibilidade Integral. XII Congresso Brasileiro de Ergonomia, 2002, Recife/PE, Anais...Recife/PE, 2002.

[24] Tostoza, L. et al. Ergonomia y Discapacidad. 1. ed. Madrid: Ministerio de Trabajo y Asuntos Sociales, 1997.

[25] Velázques, F. F. et al. Manual de Ergonomia. Madrid: Fundación Mapfre, 1995. 